\title{
Crystalline structure of a new strontium-lasalocid complex: aqua bis-(lasalocid)-strontium(II) containing nine-coordinate $\mathrm{Sr}$
}

\author{
M. Akkurt, ${ }^{\text {a* }}$ S. Öztürk Yıldırım, ${ }^{\text {a A. Melhaoui, }}{ }^{b}$ F-Z. Khardli, ${ }^{b}$ M. Mimouni, \\ V. McKee, ${ }^{c}$ and T. Ben Hadda ${ }^{b^{*}}$ \\ ${ }^{a}$ Department of Physics, Faculty of Arts and Sciences, Erciyes University, 38039 Kayseri, Turkey \\ ${ }^{b}$ Laboratoire de Chimie des Matériaux, Faculté des Sciences, 60000 Oujda, Morocco \\ ${ }^{c}$ Chemistry Department, Loughborough University, Loughborough Leics LE11 3TU, UK \\ E-mails: tbenhadda@yahoo.fr, akkurt@erciyes.edu.tr
}

\begin{abstract}
The title complex, $\left[\mathrm{Sr}\left(\mathrm{C}_{68} \mathrm{H}_{106} \mathrm{O}_{16}\right)\left(\mathrm{H}_{2} \mathrm{O}\right)\right]$, forms a pseudo-centrosymmetric monomer complex, in which one aquo (or water) ligand bridges three $\mathrm{O}$ centres of the first lasalocid anionic ligand (Lasa 2) and in which this ligand is tridentate and bonded to just one Sr atom, and the other lasalocid ligand (Lasa 1) is pentadentate and bridges the $\mathrm{Sr}$ centre within the monomer. The monomeric unit is stabilized by intramolecular $\mathrm{C}-\mathrm{H}, \ldots \mathrm{O}$ and $\mathrm{O}-\mathrm{H}$...O type-hydrogen bonding interactions.
\end{abstract}

Keywords: Lasalocid, veterinary antibiotic, strontium complex, structure

\section{Introduction}

Lasalocid A salt of sodium is one of the most commonly used veterinary antibiotics, where it has found wide spread application as an anticoccidial and to improve feed efficiency. The mechanism of action of lasalocid is clearly attributed to its ionophoric properties, because it has been reported to determine the influx of $\mathrm{Na}^{+}$in the cell of Gram positive and anaerobic bacteria, causing swelling, vacuolization, and death. At the origin of these processes, there is the property of forming lipophilic metal complexes, which can penetrate membranes and disrupt cation equilibria. 1,2

The molecular basis of this action are still debated; more specifically which of the oxygen atoms are directly involved in cation coordination. To date, this problem has been the object of many investigations almost invariably taking advantage of the concerted use of several experimental and computational techniques, which demonstrate both the relevance of the problem and its intrinsic difficulty. ${ }^{3}$ 
The identity of the various complexes formed according to the nature of the cation, to the solvent, and to the solution composition has been initially faced with optical spectroscopy and circular dichroism (CD), possibly using lanthanides as probes. ${ }^{4} \mathrm{X}$-ray diffraction data became available for several cations, among others $\mathrm{Na}^{+5}$, and $\mathrm{Ba}^{2+}{ }^{6}$ Often, it has been observed that aggregates of different stoichiometry can take place, leading to the formation of sandwiches, where the cation occupies a cavity between two ligand molecules. ${ }^{3}$ Molecular dynamic calculations have been reported both in vacuo, ${ }^{7}$ and in solvent. ${ }^{8}$ Finally, there has recently appeared a series of papers on polyoxaalkyllasalocid esters/cation complexes making use of multinuclear NMR, IR, ESI-MS, and semiempirical methods. ${ }^{9}$

It has been proposed that antibacterial and fungicidal activity and also antitumor and antiHIV-integrase inhibition of antibiotics lie in their ability to chelate the essential metals, which the microorganisms need in their metabolism. ${ }^{\text {e-g }}$

\section{Results and Discussion}

We report the synthesis and structure of the first compound of a series of strontium(II) complexes that is readily prepared as its pure stochioisomer ligand/metal (2/1). This new strontium(II) complex, deriving from a lasalocid/ strontium coordination, is obtained through a simple and economical synthetic method. The reaction of lasalocid acid (1) (Figure 1), with strontium salt under ordinary atmosphere, with controlling $\mathrm{pH}(\mathrm{pH}>8)$, provides a stable coordination product (Figure 2), the aquo-strontium-bis-lasalocid, which is characterised by $\mathrm{X}$ ray (Figure 3).

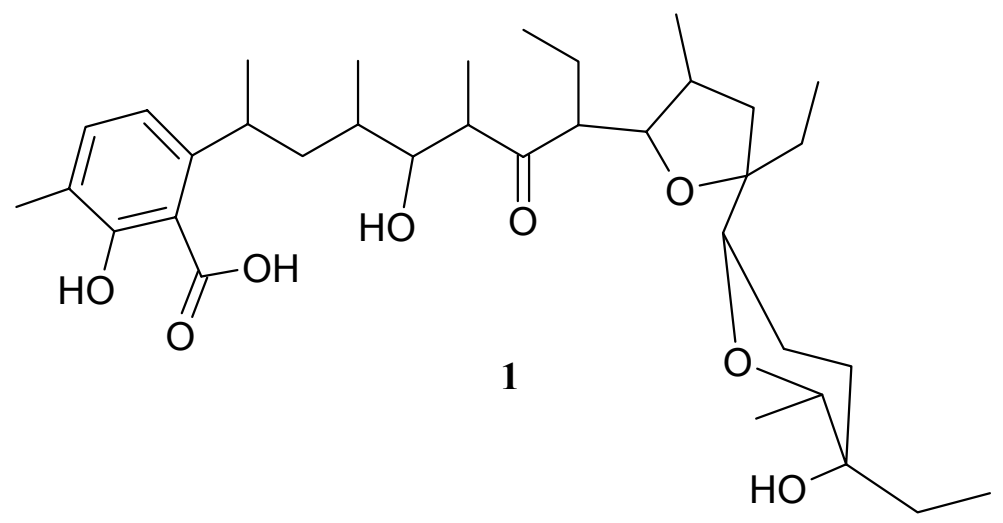

Figure 1. Structure of lasalocide acid 1. 


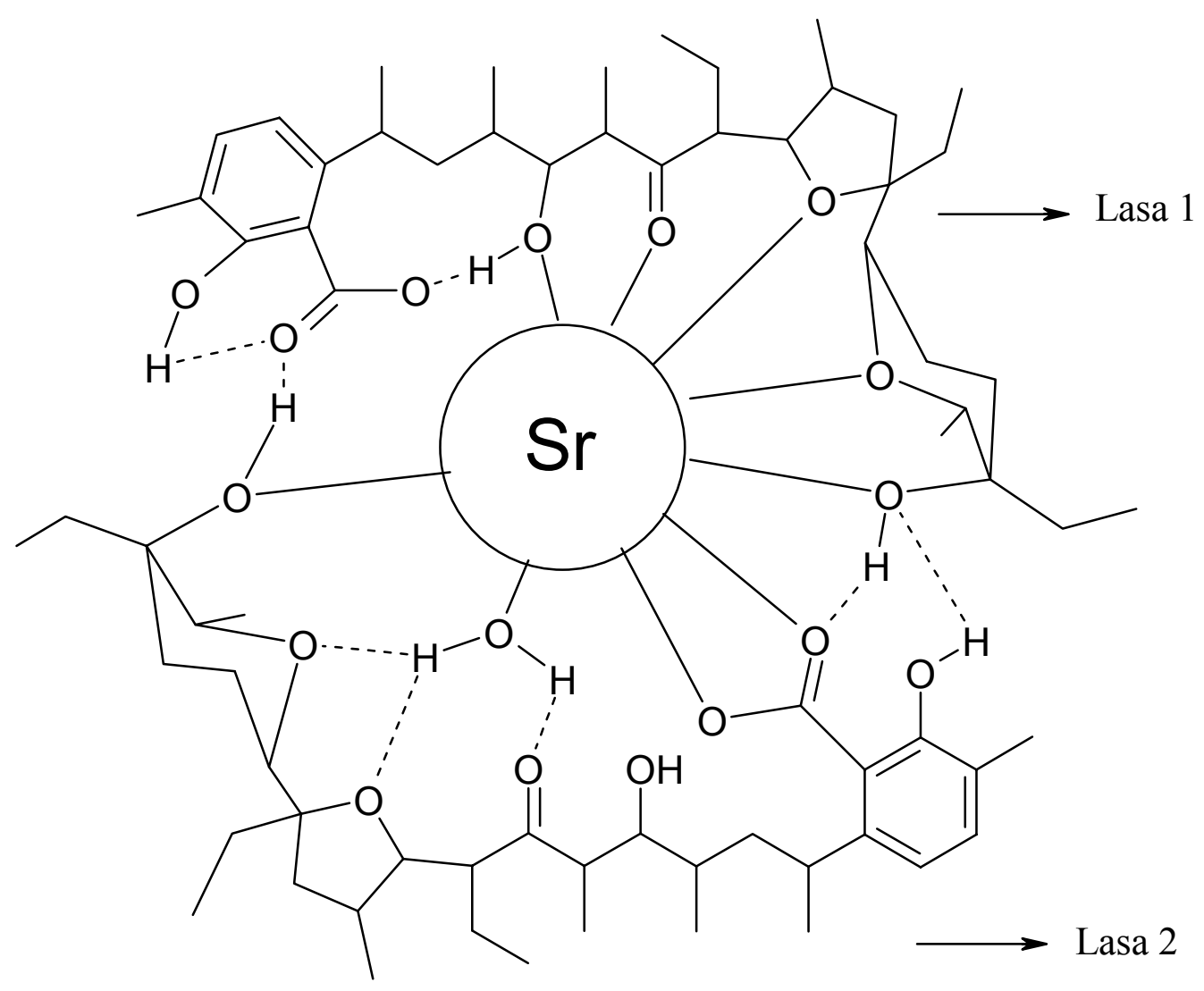

Figure 2. The title complex $\left[\mathrm{Sr}(\mathrm{Lasa})_{2}\left(\mathrm{OH}_{2}\right)\right]$.

The title complex, $\left[\mathrm{Sr}\left(\mathrm{C}_{68} \mathrm{H}_{106} \mathrm{O}_{16}\right)\left(\mathrm{H}_{2} \mathrm{O}\right)\right]$, crystallizes with nine-coordinated Sr atom threedimensionally interconnected into a framework structure. The crystallographically dependent water molecule is located on an axial site. These two lasalocid ligands (Lasa 1 and Lasa 2) are tied together by a three-dimensional hydrogen-bonding network. These monomeric units are not stacked by any Van der Waals forces between the coordination spheres.

Since the coordination properties of the two molecules of lasalocid ligands are different, it is concluded that the two lasalocid ligands are not simultaneously coordinated. To have a clear idea about the coordinative aspect of the two ligands, the view for the complex $\left[\mathrm{Sr}(\mathrm{Lasa})_{2}\left(\mathrm{OH}_{2}\right)\right]$ ) has been added here as shown in Figure 2.

\section{Conclusions}

In conclusion, we describe here what is to our knowledge the first solid-state structure obtained with a strontium-lasalocid complex. The tetra-butyl ammonium salt of lasalocid is able to form a stable 2:1 (ligand : metal) complex with divalent cations such as strontium(II). The structure of this complex is completely different with the respective complexes with other divalent cations 
$\left(\mathrm{Mg}^{2+}\right.$ and $\left.\mathrm{Ca}^{2+}\right) .{ }^{15}$ A preliminary biological activity of the Sr-Lasalocid ester on fungus $\mathrm{F}$. oxysporum was studied in vitro at Oujda. It is shown that this compound is biologically active. This result is very important for future agricultural applications and deserves to be extended to a wide series of transition metals [Ru(II), Co(II), Fe(II)].

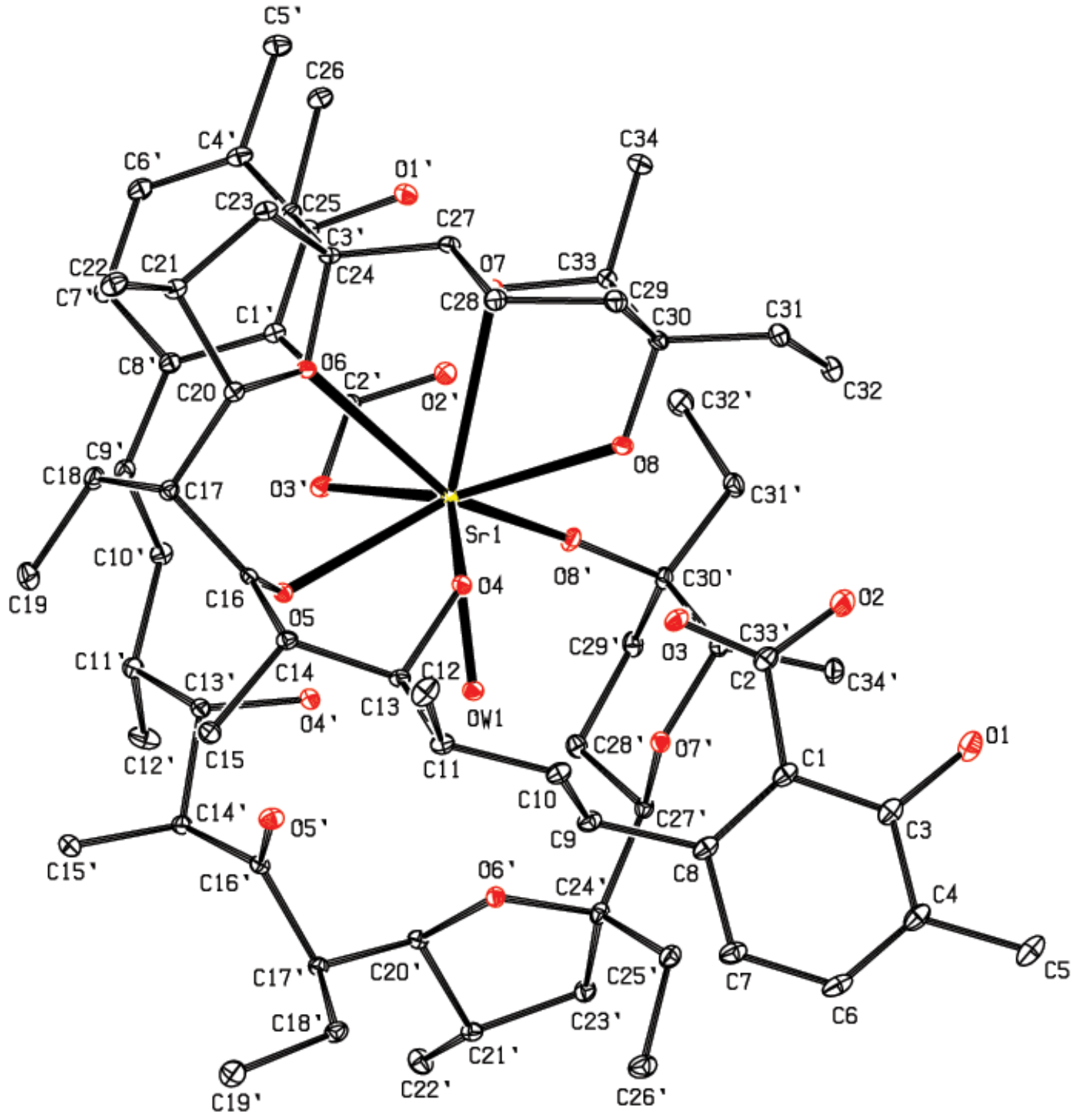

Figure 3. An ORTEP view of the title compound, with the atom-numbering scheme and $10 \%$ probability displacement ellipsoids. $\mathrm{H}$ atoms have been omitted for clarity. Displacement ellipsoids are drawn at the $10 \%$ probability level. 


\section{Experimental Section}

Preparation of complex (I). A solution of tetramethylammonium-lasalocid free salt (6.64 g, 2 mmole, prepared in $20 \mathrm{~mL}$ of $\left.\mathrm{CHCl}_{3}\right)$ was stirred with $0.1 \mathrm{M}$ aqueous $\mathrm{SrCl}_{2}(0.793 \mathrm{~g}, 1 \mathrm{mmole}$, prepared in $50 \mathrm{~mL}$ of $\mathrm{H}_{2} \mathrm{O}$ ). The mixture was stirred at $20^{\circ} \mathrm{C}$ for $4 \mathrm{~h}$ under argon in the dark. The organic layer was then dried over anhydrous $\mathrm{Na}_{2} \mathrm{SO}_{4}$, filtered and evaporated. The solid residue was dissolved in $\mathrm{MeOH}$ and the solvent was left to evaporate at $20{ }^{\circ} \mathrm{C}$ for 1 week in the dark. Yellow crystals obtained proved suitable for X-ray analysis (65\% Yield).

Crystal structure analysis. The crystal structure of the title compound, $\mathrm{C}_{68} \mathrm{H}_{108} \mathrm{O}_{17} \mathrm{Sr}$, has been determined at room temperature. Diffraction data were collected using a Bruker SMART APEXII CCD diffractometer system, using graphite-monochromated $\mathrm{MoK}_{\alpha}$ radiation.

The crystallographic details are given in Table 1. The structure was solved by direct methods by using SIR-97 program and refined by least-squares on $\mathrm{F}_{\text {obs }}{ }^{2}$ and by using SHELXL-97 programs. $\mathrm{O} 1, \mathrm{O} 4, \mathrm{O} 8, \mathrm{O}^{\prime}, \mathrm{O}^{\prime}, \mathrm{O}^{\prime}$ and $\mathrm{H}$ atoms belonging to the coordinated water molecules were located in a difference Fourier map and refined with mean O-H distances of 0.855(3) A, freely. All other $\mathrm{H}$ atoms were located in calculated positions and treated as riding on their parent atoms, with $\mathrm{C}-\mathrm{H}=0.96\left(\mathrm{CH}_{3}\right), 0.97\left(\mathrm{CH}_{2}\right)$ or $0.98 \AA(\mathrm{CH})$, and with $\mathrm{U}_{\text {iso }}(\mathrm{H})=1.5 \mathrm{U}_{\text {eq }}\left(\mathrm{CH}_{3}\right)$ or $1.2 \mathrm{U}_{\mathrm{eq}}\left(\mathrm{CH}_{2}, \mathrm{CH}\right)$. A displacement ellipsoid plot with the atomic numbering scheme of the title compound is shown in figure 3; with selected bond lengths and bond angles, and the details of the hydrogen-bonding geometry in Tables 2 and 3, respectively.

The average $\mathrm{Sr}-\mathrm{O}[2.653(2) \AA]$ distance, consistent with usual distances for nine-coordinated $\mathrm{Sr}^{\mathrm{II}}$ ions $[\mathrm{Sr}-\mathrm{O} 2.564(3)-2.967(3) \AA] .{ }^{13}$ Within the ligands, other geometric parameters $(\mathrm{C}-\mathrm{O}$ and $\mathrm{C}-\mathrm{C}$ distances, and $\mathrm{O}-\mathrm{C}-\mathrm{O}$ and $\mathrm{O}-\mathrm{C}-\mathrm{C}$ angles) all lie in the expected ranges. ${ }^{14}$ The crystal structure is stabilized by the intramolecular $\mathrm{O}-\mathrm{H}_{\ldots} . \mathrm{O}$ and $\mathrm{C}-\mathrm{H} \ldots \mathrm{O}$ type-hydrogen bonding interactions (Table 3 ). 
Table 1. Crystal and experimental data

\begin{tabular}{ll}
\hline Formula & $\mathrm{C}_{68} \mathrm{H}_{108} \mathrm{O}_{17} \mathrm{Sr}$ \\
\hline Formula weight & 1285.17 \\
Crystal system & orthorhombic \\
Space group & $\mathrm{P} 2_{1} 2_{1} 2_{1}($ No. 19$)$ \\
& $Z=4$ \\
& $a=17.3910(12) \AA$ \\
& $b=18.4288(13) \AA$ \\
& $c=21.3794(15) \AA$ \\
& $V=6852.0(8) \AA^{3}$ \\
& $D_{\mathrm{x}}=1.246 \mathrm{~g}^{-3} \mathrm{~cm}^{-3}$ \\
& $\mu\left(\mathrm{MoK}_{\alpha}\right)=0.852 \mathrm{~cm}^{-1}$ \\
& $T=293 \mathrm{~K}$ \\
& $0.48 \mathrm{~mm}$ \\
Crystal size & $F(000)=2760$ \\
Radiation & $0.18 \mathrm{x} 0.37 \mathrm{x}$ \\
& MoK \\
& $R=0.0323$ \\
& $R_{\mathrm{w}}=0.0722$ \\
& 17056 \\
No. of unique data measured & 14341 \\
No. of observed data with $[I \geq 2 \sigma(I)]$ & 807 \\
No. of parameters & 1.02 \\
Goodness-of-fit & $(\Delta \rho)_{\max }=0.41 \mathrm{e} . \AA^{-3}$ \\
& $(\Delta \rho)_{\min }=-0.66 \mathrm{e} . \AA^{-3}$ Bruker SMART APEX-II CCD \\
Measurements & diffractometer ${ }^{10}$ \\
Structure determination & $S I R 97$ program ${ }^{11}$ \\
Refinement & full matrix least-squares SHELXL-97 program ${ }^{12}$ \\
\hline
\end{tabular}

Table 2. Selected bond lengths $(\AA)$ and angles $\left({ }^{\circ}\right)$

$\begin{array}{llll}\mathrm{Sr} 1-\mathrm{OW} 1 & 2.4758(15) & \mathrm{O} 1-\mathrm{C} 3 & 1.349(3) \\ \mathrm{Sr} 1-\mathrm{O} 4 & 2.8693(13) & \mathrm{O} 2-\mathrm{C} 2 & 1.259(3) \\ \mathrm{Sr} 1-\mathrm{O} 5 & 2.5597(13) & \mathrm{O} 3-\mathrm{C} 2 & 1.255(3) \\ \mathrm{Sr} 1-\mathrm{O} 6 & 2.8012(13) & \mathrm{O} 4-\mathrm{C} 13 & 1.446(2) \\ \mathrm{Sr} 1-\mathrm{O} 7 & 2.7244(13) & \mathrm{O} 5-\mathrm{C} 16 & 1.219(2) \\ \mathrm{Sr} 1-\mathrm{O} 8 & 2.5379(15) & \mathrm{O} 6-\mathrm{C} 20 & 1.449(2) \\ \mathrm{Sr} 1-\mathrm{O} 3^{\prime} & 2.5906(14) & \mathrm{O} 6-\mathrm{C} 24 & 1.475(2) \\ \mathrm{Sr} 1-\mathrm{O} 8^{\prime} & 2.6652(14) & \mathrm{O} 7-\mathrm{C} 27 & 1.442(2) \\ \mathrm{O} 8-\mathrm{C} 30 & 1.433(2) & \mathrm{O} 7-\mathrm{C} 33 & 1.449(2)\end{array}$




\begin{tabular}{llll} 
OW1 - Sr1 - O4 & $72.04(4)$ & $\mathrm{Sr} 1-\mathrm{O} 4-\mathrm{C} 13$ & $116.54(10)$ \\
OW1 - Sr1 - O5 & $69.94(4)$ & $\mathrm{Sr} 1-\mathrm{O} 5-\mathrm{C} 16$ & $119.22(11)$ \\
OW1 - Sr1 - O6 & $133.90(4)$ & $\mathrm{Sr} 1-\mathrm{O} 6-\mathrm{C} 20$ & $131.52(10)$ \\
OW1 - Sr1 - O7 & $161.43(4)$ & $\mathrm{Sr} 1-\mathrm{O} 6-\mathrm{C} 24$ & $115.95(10)$ \\
OW1 - Sr1 - O8 & $101.11(5)$ & $\mathrm{O} 7-\mathrm{Sr} 1-\mathrm{O} 8$ & $61.33(4)$ \\
Sr1 - O7 - C27 & $113.61(10)$ & $\mathrm{O} 6-\mathrm{Sr} 1-\mathrm{O} 8$ & $101.61(4)$ \\
Sr1 - O7 - C33 & $106.15(10)$ & $\mathrm{O} 5-\mathrm{Sr} 1-\mathrm{O} 8$ & $134.97(4)$ \\
Sr1 - O8 - C30 & $126.08(12)$ & $\mathrm{O} 6-\mathrm{Sr} 1-\mathrm{O} 7$ & $60.58(4)$ \\
O5 - Sr1 - O7 & $126.13(4)$ & $\mathrm{O} 5-\mathrm{Sr} 1-\mathrm{O} 6$ & $65.57(4)$ \\
O4 - Sr1 - O7 & $104.63(4)$ & $\mathrm{O} 4-\mathrm{Sr} 1-\mathrm{O} 8$ & $69.87(4)$ \\
O4 - Sr1 - O5 & $65.39(4)$ & $\mathrm{O} 4-\mathrm{Sr} 1-\mathrm{O} 6$ & $79.04(4)$ \\
\hline
\end{tabular}

Table 3. Hydrogen-bonding geometry $\left(\AA,{ }^{\circ}\right)$.

\begin{tabular}{|c|c|c|c|c|}
\hline D-H...A & D-H & H...A & D...A & D-H...A \\
\hline $\mathrm{O} 1-\mathrm{H} 1 \mathrm{O} \ldots \mathrm{O} 2$ & $1.00(3)$ & $1.47(3)$ & $2.438(2)$ & $161(2)$ \\
\hline $\mathrm{O} 4-\mathrm{H} 4 \mathrm{O} \ldots \mathrm{O} 3$ & $0.83(2)$ & $2.00(2)$ & $2.802(2)$ & $163(2)$ \\
\hline $\mathrm{O} 8$ - H8O . . . O 3 & $0.91(3)$ & $1.68(3)$ & $2.551(2)$ & $159(3)$ \\
\hline $\mathrm{O} 1^{\prime}-\mathrm{H}_{1} \mathrm{O}^{\prime} \ldots \mathrm{O} 2^{\prime}$ & $0.87(3)$ & $1.71(3)$ & $2.486(2)$ & $149(3)$ \\
\hline O4' - H4O' . . O $3^{\prime}$ & $0.81(3)$ & $2.13(3)$ & $2.880(2)$ & $154(3)$ \\
\hline $\mathrm{O}^{\prime}-\mathrm{H} 8 \mathrm{O}^{\prime} \ldots \mathrm{O} 2^{\prime}$ & $0.81(2)$ & $2.00(2)$ & $2.666(2)$ & $140(2)$ \\
\hline OW1 - HW1 . . O6' & $0.84(3)$ & $2.52(3)$ & $2.9648(19)$ & $114(2)$ \\
\hline OW1 - HW1 . . O7' & $0.84(3)$ & $1.94(3)$ & $2.7652(19)$ & $167(3)$ \\
\hline OW1 - HW2 . O5' & $0.77(3)$ & $2.28(3)$ & $3.033(2)$ & $166(3)$ \\
\hline $\mathrm{C}^{\prime}-\mathrm{H} 5^{\prime} 1 \ldots \mathrm{O} 1^{\prime}$ & 0.96 & 2.24 & $2.723(3)$ & 110 \\
\hline C5 - H5A ... O1 & 0.96 & 2.27 & $2.743(3)$ & 110 \\
\hline C9' - H9'2 . . . O3' & 0.97 & 2.25 & $2.805(2)$ & 115 \\
\hline C9 - H9B . . . . O3 & 0.97 & 2.36 & $2.811(3)$ & 107 \\
\hline C10 - H10B . . O3 & 0.97 & 2.40 & $3.008(3)$ & 120 \\
\hline C10' - H10C . . . O4' & 0.97 & 2.50 & $2.916(3)$ & 105 \\
\hline C13 - H13 . . . . OW1 & 0.98 & 2.50 & $3.245(2)$ & 132 \\
\hline C28 - H28A . . O6 & 0.97 & 2.52 & $2.915(2)$ & 104 \\
\hline C28' - H28C . . . O4' & 0.97 & 2.57 & $3.494(2)$ & 160 \\
\hline C32' - H32E . . O $2^{\prime}$ & 0.96 & 2.51 & $3.415(3)$ & 157 \\
\hline
\end{tabular}

Note: CCDC 664624 contains the supplementary crystallographic data for this paper. These data can be obtained free of charge from The Cambridge Crystallographic Data Centre via www.ccdc.cam.ac.uk/data_request/cif. 


\section{Acknowledgements}

The authors acknowledge Professor Georges Jeminet and the "Agence universitaire de la francophonie", for sending us the ionophores ligands (lasalocid, monensin and calcimycin). This work was also supported by the PGR-BH-2005 and CUD-UMP-BH-2007 Grants from the Ministry of National Education of Morocco.

\section{References}

1. Crandall, L. W.; Hamill, R. L. In Kirk-Othmer. Encyclopedia of Chemical Technology, 4th Edn.; Wiley: New York, 1992; Vol. 3, pp 306.

2. Lindsay, D. S.; Blagburn, B. L. In: Veterinary Pharmacology and Therapeutics, Adams, H. R., Ed.; Blackwell Publishing Professional: Ames, IA, 2001; pp 992.

3. Lindoy, L. F. Coord.Chem. Rev. 1996, 148, 349.

4. (a) Tsukube, H.; Takeishi, H.; Yoshida, Z. Inorg. Chim. Acta 1996, 251, 1. (b) AguilarCaballos, M. P.; Goemez-Hens, A.; Perez-Bendito, D. Talanta 1999, 48, 209.

5. Schmidt, P. G.; Wang, A. H. J.; Paul, I. C. J. Am. Chem. Soc. 1974, 96, 6189.

6. Johnson, S. M.; Herrin, J.; Liu, S. J.; Paul, I. C. J. Am. Chem. Soc. 1970, 92, 4428.

7. (a) Malfreyt, P.; Lyazghi, R.; Dauphin, G.; Pascal, Y; Juillard, J. J. Chem. Soc. Perkin Trans.2 1996, 85, 1971. (b) Tissier, M.; Mousset, G.; Juillard, J. J. Chem. Soc. Faraday Trans. 1989, 2, 1337.

8. Lyazghi, R.; Cuer, A.; Dauphin, G.; Juillard, J. J. Chem. Soc. Perkin Trans 2 1992, 35.

9. (a) Pankiewicz, R.; Pawlowska, A.; Schroeder, G.; Przybylski, P.; Brzezinski, B.; Bartl, F. J. Mol. Struct. 2004, 694, 55. (b) Pankiewicz, R.; Pawlowska, A.; Schroeder, G.; Przybylski, P.; Brzezinski, B.; Bartl, F. J. Mol. Struct. 2004, 694, 155. (c) Pankiewicz, R.; Schroeder, G.; Przybylski, P.; Brzezinski, B. J. Mol. Struct. 2005, 733, 155. (d) Pankiewicz, R.; Schroeder, G.; Przybylski, P.; Brzezinski, B. J. Mol. Struct. 2005, 733, 217.

10. Bruker, 2005, APEX2 (Version 2.1) and SAINT (Version 7.23A). Bruker AXS Inc., Madison, Wisconsin, USA.

11. Altomare, A.; Burla, M. C.; Camalli, M.; Cascarano, G.; Giacovazzo, C.; Guagliardi, A.; Moliterni, A. G. G.; Polidori, G. L. Spagna, R. J. Appl. Crystallogr. 1999, 32, 115.

12. Sheldrick, G.M., 1997, SHELXL97. Program for the Refinement of Crystal Structures, University of Göttingen, Germany.

13. Stein, I. and Ruschewitz, U. Acta Cryst. 2005, E61, m141-m143.

14. Allen, F. H.; Kennard, O.; Watson, D. G.; Brammer, L.; Orpen, A. G. and Taylor R. $J$. Chem. Soc. Perkin Trans. 2 1987, 2, S1-S19.

15. Pankiewicz, R.; Remlein-Starost, D.; Schroeder, G.; Brzezinski, B. J. Mol. Struct. 2006, $783,136$. 